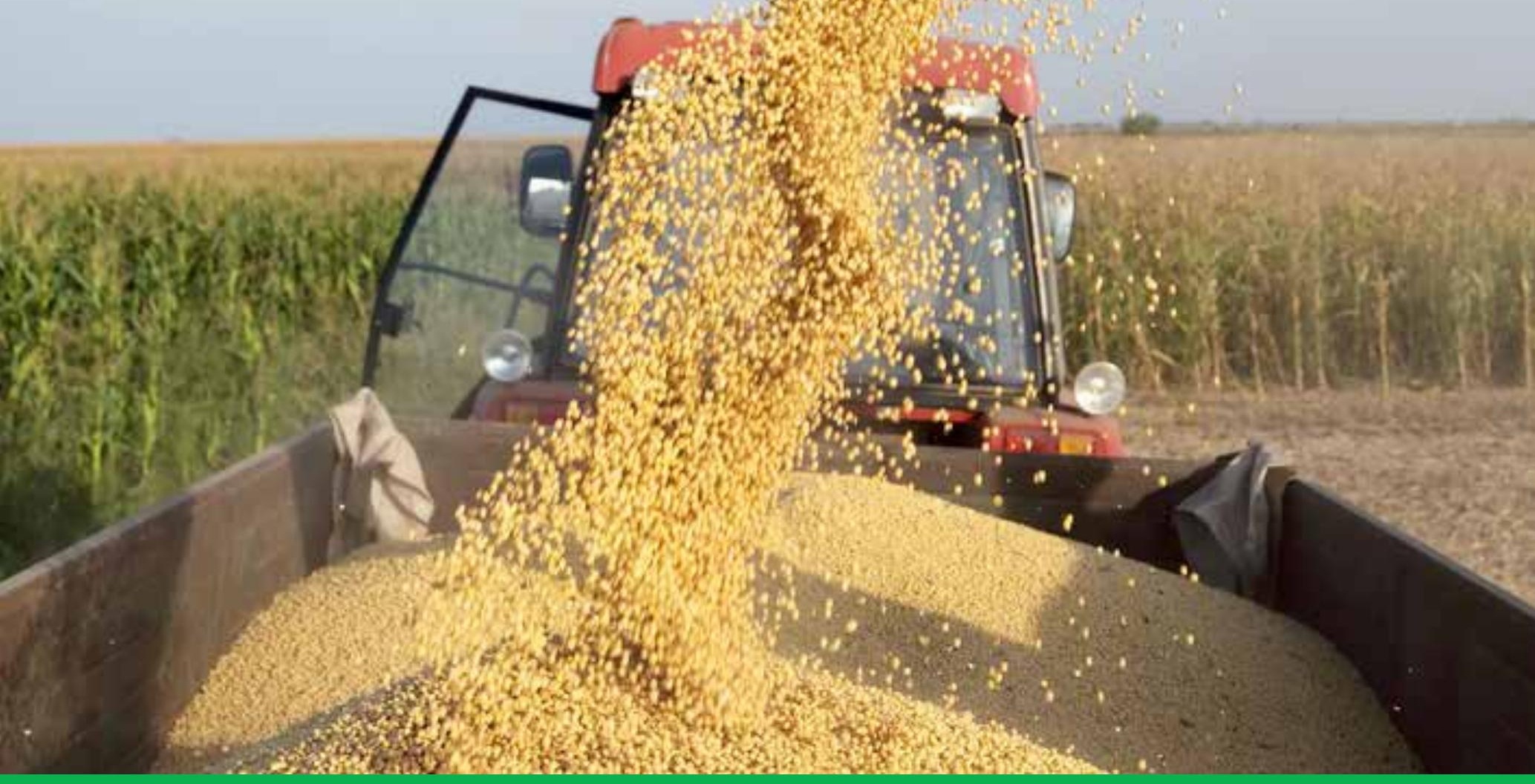

\title{
Impact assessment of the Dutch transition towards certified soy
}

Robert Hoste and Lucas Judge 



\section{Impact assessment of the Dutch transition towards certified soy}

Robert Hoste and Lucas Judge

This study was carried out by Wageningen Economic Research and was commissioned and co-financed by the Stichting Ketentransitie Verantwoorde Soja (Foundation for the Transition to Responsible Soy), Nevedi (The Dutch Feed Industry Association), WWF Netherlands and MVO (The Netherlands Oils and Fats Industry), from the Top Consortia for Knowledge and Innovation Allowance of the Ministry of Agriculture, Nature and Food Quality (formerly known as the Ministry of Economic Affairs, project number BO 31.03-005-001-LEI) 
Hoste, R., and L. Judge, 2018. Impact assessment of the Dutch transition towards certified soy. Wageningen, Wageningen Economic Research, Report 2018-003. 34 pp.; 4 fig.; 6 tab.; 21 ref.

De Nederlandse diervoedersector is overgegaan op uitsluitend gebruik van gecertificeerde soja in diervoeder, waarvan een deel RTRS-gecertificeerd. Het draagvlak van deze overgang door partijen in de Nederlandse productieketens van dierlijke producten is gemeten, evenals consequenties van duurzaamheidsthema's in RTRS-gecertificeerde sojaproductie. Geconcludeerd wordt dat RTRSgecertificeerde productie meer duurzaam is op bepaalde thema's, maar een alomvattende conclusie over de duurzaamheid van RTRS-gecertificeerde productie ten opzichte van andere sojaproductie kan bij gebrek aan informatie niet worden getrokken.

The Dutch animal feed sector has made a transition to fully use certified soy in animal feed, part of which is RTRS certified. The support of this transition by partners in the Dutch supply chains of animal products is measured, as well as consequences on sustainability topics in RTRS-certified soy production. It is concluded that RTRS-certified soy production is more sustainable on some topics, but a comprehensive conclusion cannot be drawn, as the available data are very limited.

Key words: Soy, Responsible, Certified, RTRS, Producers, Demand, Transition

This report can be downloaded for free at https://doi.org/10.18174/451268 or at www.wur.eu/economic-research (under Wageningen Economic Research publications).

(C) 2018 Wageningen Economic Research

P.O. Box 29703, 2502 LS The Hague, The Netherlands, T +31 (0)70 33583 30,

E communications.ssg@wur.nl, http://www.wur.eu/economic-research. Wageningen Economic Research is part of Wageningen University \& Research.

\section{(cc) BY-NC}

For its reports, Wageningen Economic Research utilises a Creative Commons Attributions 3.0 Netherlands license.

(c) Wageningen Economic Research, part of Stichting Wageningen Research, 2018

The user may reproduce, distribute and share this work and make derivative works from it. Material by third parties which is used in the work and which are subject to intellectual property rights may not be used without prior permission from the relevant third party. The user must attribute the work by stating the name indicated by the author or licensor but may not do this in such a way as to create the impression that the author/licensor endorses the use of the work or the work of the user. The user may not use the work for commercial purposes.

Wageningen Economic Research accepts no liability for any damage resulting from the use of the results of this study or the application of the advice contained in it.

Wageningen Economic Research is ISO 9001:2008 certified.

Wageningen Economic Research Report 2018-003 | Project code 2282100041

Cover photo: Shutterstock 


\section{Contents}

Preface $\quad 5$

$\begin{array}{ll}\text { Summary } & 6\end{array}$

S.1 Key findings $\quad 6$

S.2 Complementary findings 6

S.3 Method 6

2.1 Certified soy 10

$\begin{array}{ll}2.2 \text { Measuring impact } & 10\end{array}$

2.3 Data collection for Impact analysis $\quad 12$

$\begin{array}{lll}3.1 & \text { Introduction } & 13\end{array}$

3.2 Support to transition towards RTRS 13

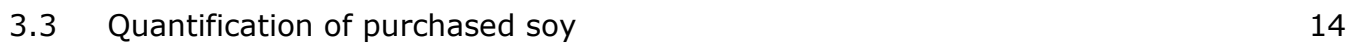

3.4 Ambitions, standards and agreements 16

3.4.1 General programmes and schemes 16

3.4.2 Sectoral ambitions related to certified soy 16

$\begin{array}{ll}3.4 .3 \text { Pig meat } & 17\end{array}$

3.4.4 Broiler meat $\quad 17$

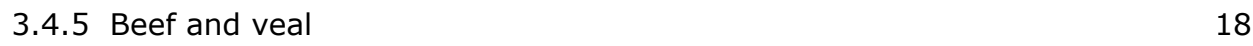

3.4.6 Eggs 18

3.4.7 Dairy 19

3.4.8 Animal feed 19

3.4.9 Retailers 19

$\begin{array}{lll}4.1 & \text { Introduction } & 21\end{array}$

$\begin{array}{lll}4.2 & \text { RTRS soy production } & 21\end{array}$

$\begin{array}{lll}4.3 & \text { Projects on certified soy production } & 22\end{array}$

4.4 Environmental sustainability within sample $\quad 24$

$\begin{array}{lll}4.5 & \text { Social sustainability } & 24\end{array}$

$\begin{array}{ll}\text { References and websites } & \mathbf{2 8}\end{array}$

$\begin{array}{lll}\text { Appendix } 1 & \text { Original list of indicators } & 30\end{array}$

Appendix 2 Dutch RTRS members and RTRS suppliers to the Dutch market 33 



\section{Preface}

The Dutch animal feed sector has made a transition to fully use certified soy in animal feed. The support of this transition by partners in the Dutch supply chains of animal products is measured, as well as consequences for sustainability topics in RTRS-certified soy production.

Measuring the impact of the transition towards certified soy on the sustainability of soy production has shown to be quite a challenge, due to lack of data. The project however was an interesting approach with positive cooperation from commercial parties and NGOs involved.

The Stichting Ketentransitie Verantwoorde Soja (Foundation for the Transition to Responsible Soy), Nevedi (The Dutch Feed Industry Association), WWF Netherlands and MVO (The Netherlands Oils and Fats Industry) were formally involved in the project. IDH, Natuur\&Milieu, Solidaridad, IUCN, OxfamNovib and BothEnds also contributed to the project, by sharing information, insights and contacts. The project working group consisted of Nevedi, MVO, IDH, WWF, Solidaridad and Wageningen Economic Research.

We thank all participants in this project for their support and valuable insights.

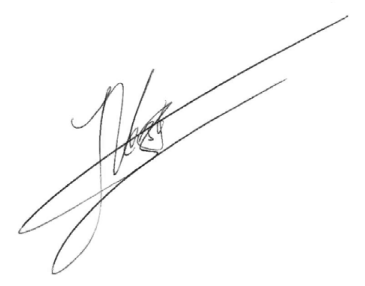

Prof.dr.ir. J.G.A.J. (Jack) van der Vorst General Director Social Sciences Group (SSG)

Wageningen University \& Research 


\section{Summary}

\section{S.1 Key findings}

\section{RTRS-certified producers are more sustainable on some issues}

The partial transition of the Dutch animal production sectors towards RTRS-certified soy is likely to support a sustainable production of the soy needed for animal feed.

Although an impact assessment is based on a limited number of topics and soy producers, it is found that RTRS-certified producers are in in the lead concerning the registration of protected areas above legal requirements and Forest Code. Farmers invest in agrochemical storage and disposal management in order to attain certification and legal compliance, with total investments amounting to USD $2.6 \mathrm{~m}$ in 2016. Farms have installed Dialogue and communication mechanisms, and investments to achieve compliance with labour law and standards amounted to USD $6.0 \mathrm{~m}$ in 2016 .

Based on these findings, it can be concluded that at least on some topics, an improvement has been achieved in the sustainability of soy production after RTRS certification. However, a comprehensive conclusion cannot be drawn, as the available data are very limited.

\section{S.2 Complementary findings}

\section{For animal feed in the Netherlands all soy is certified}

The joint approach of the Dutch feed and animal production sectors and retail towards using certified soy in animal production has resulted in a transition to fully use of certified soy, of which about $72 \%$ is RTRS-certified soy and the rest certified according to other soy production standards that comply with the FEFAC Sourcing Guidelines.

This transition is the result of retail agreements (for animal products meat, eggs and dairy, where only RTRS or equivalent soy should be used in animal production) and supply chain programmes (Varkensvlees van morgen, Kip van morgen, Duurzame Zuivelketen).

The Dutch ambition to fully use RTRS-certified soy has been amended in 2014 into a two-track policy: for domestic consumption of animal products RTRS-certified soy was to be used; for other animal production the necessary soy in animal feed should comply with a soy standard according to FEFAC Guidelines.

\section{Netherlands is an important player in RTRS}

The Netherlands is an important player in RTRS-certified soy consumption, using over $1.2 \mathrm{~m}$ tonnes of soy, which reflects $30 \%$ of the worldwide RTRS soy uptake in 2016.

\section{S.3 Method}

An impact assessment has been performed on the sustainability consequence in soy production of the transition towards using certified soy in animal feed in the Netherlands. To this end, both the demand side and production side have been analysed. Certified soy is defined as soy where the production is compliant with FEFAC Sourcing Guidelines, with special attention to RTRS-certified soy. In practice the feed industry prefers the term 'responsible' soy, a term which, however, is being opposed by NGOs.

In this project indicators and methods were developed to measure the impact on the supply and demand side and data sources for these indicators were identified. These indicators, methods and data 
sources are being used subsequently in 2013, 2014 and 2015 to analyse the annual progress of the transition and its impact.

Purchase indicators (demand side) have been defined and measured in the a) support of the transition towards RTRS by supply chain partners, b) quantification of certified soy use, c) sector ambitions, industry standards and retail and supply chain agreements.

The supply side concerns the extent to which the specific purchase of certified soy by Dutch stakeholders makes the cultivation of soy in the countries of origin more sustainable. Based on a developed Theory of Change relevant sustainability indicators on the supply side (soy production) were defined. Data were collected within a sample of IDH projects. 


\section{Introduction}

Business community interest in increasing the sustainability of the soy used in animal feed led to the creation of the Stichting Ketentransitie Verantwoorde Soja (Foundation for the Transition to Responsible Soy) (abbreviated SKT). The ambition of SKT was to have a $100 \%$ use of responsible soy in animal feed by 2015 for Dutch companies. SKT discontinued according to plan, and the ambition was pursued by Nevedi, the umbrella organisation of the feed industry in the Netherlands. However, due to lack of demand for RTRS soy in countries importing Dutch animal products, the ambition was amended: soy use for domestic consumption of animal products should be based on RTRS soy in animal feed; soy in feed for animals meant for non-domestic consumption should comply with a somewhat lower standard.

This report presents the results of a project to monitor the results of the transition towards $100 \%$ certified soy in the Dutch Animal feed sector between 2012 and 2014, where certification focuses on ecological, social and economic sustainability. Certified soy is defined as soy where the production is compliant with FEFAC Sourcing Guidelines, with special attention to RTRS-certified soy. In practice the feed industry prefers the term 'responsible' soy, a term which, however, is being opposed by NGOs.

\section{Aim}

The project aims to show with an annual impact assessment that the transition towards the use of certified soy in the Dutch animal feed industry during the period 2012-2014 improves the sustainability of the soy supply chain.

\section{Background}

The Dutch animal feed sector aims to improve the sustainability of their raw materials. Therefore the Dutch feed industry has started a transition process towards using certified soy as a raw material.

\section{Approach}

The innovation challenge encompasses the development of methods and indicators for measuring the improvement of social and ecological sustainability of certified soy cultivation (supply side) and market acceptance in the Netherlands (demand side). Cultivation indicators to measure impact on sustainability are commodity specific and even region specific. Therefore, cultivation indicators to measure impact on sustainability for other commodities (Waarts et al., 2013; Kuit and Waarts, 2014) are not directly usable for soy, although they can help to define these. Furthermore, impact assessments for other commodities focus on poverty, whereas for soy the focus is on environmental and societal impact. Finally, after the indicators and methods have been defined, these have been applied for the years 2012, 2013, and 2014 (2015 and 2016 have been added as well) to analyse the annual improvement of the sustainability of the soy production. While finalising this report was delayed, we took the opportunity to include 2015 and 2016 results of the impact analysis in production.

The main question was whether the transition process towards using RTRS-certified soy in the Dutch feed industry has contributed to an improvement of the sustainability of soy production. This is measured both on the supply side (social ecological impact of RTRS-certified soy cultivation) and on the demand side (market acceptance of RTRS-certified soy in the Netherlands).

The project is part of the Public Private Partnership Feed4Foodure, with industry, NGOs and Dutch government. The project aims to support a sustainable, healthy and future oriented animal husbandry in the Netherlands, according to the strategy in the 'Uitvoeringsagenda duurzame veehouderij' and the Innovation Contract of the Topsector Agri\&Food. The impact analysis is financed by a subsidy from the Ministry of Agriculture, Nature and Food Quality (formerly known as the Ministry of Economic Affairs), a cash contribution from SKT and contributions from NGOs and the business community. 
Wageningen Economic Research, SKT, Nevedi, WWF and MVO were formally involved in the project. Additionally IDH, Natuur\&Milieu, Solidaridad, IUCN, OxfamNovib and BothEnds contributed to the project, by sharing information, insights and contacts. The project working group consisted of Nevedi, MVO, IDH, WWF, Solidaridad and Wageningen Economic Research. All involved parties were participating in a Working Group that focused on setting up the list of indicators to be measured.

Collected information has also been used in the reports of the Soy Fast Track Fund of IDH. Hoste and Judge (2015) presented first results of the impact analysis. 


\section{Methodology}

\section{$2.1 \quad$ Certified soy}

Certified soy is defined as soy where the production is compliant with FEFAC Sourcing Guidelines. Special attention is given to RTRS-certified soy. In practice the feed industry prefers the term 'responsible' soy, a term which, however, is being opposed by NGOs, see Soy Coalition (2015) and Nevedi $(2016,2017)$. In the beginning of the project, certified soy was defined as RTRS-certified soy, or equivalent. Equivalency, however, was not clearly defined. During the transition period it was found that the supply and the demand for RTRS-certified soy was not in balance: the supply at that time exceeded the demand of customers of animal products.

Meanwhile FEFAC initiated a process to broaden the demand for certified soy. Their Soy Sourcing Guidelines aim to contribute to a mainstream transition towards certified soy. The Guidelines give a framework to evaluate soy schemes. The Guidelines include issues on legal compliance, working conditions, environmental responsibility, good agricultural practices, land rights, and community relations (FEFAC, 2016).

The advantage of broadening the demand is that a large and stable demand is easier to fill by producers (and traders) than a rather small Dutch market demand. The requirements in the FEFAC Sourcing Guidelines are not in all issues as strict as the RTRS, but the net result in terms of sustainability improvements was assumed to become larger, due to the bigger volume covered by this standard. Another positive consequence is that broadening the demand for certified soy cushions a potential competitive disadvantage. During this process, the Stichting Ketentransitie discontinued according to plan, and the ambition was pursued by Nevedi, however it was amended into a two-track policy. Soy use for domestic consumption of animal products should be based on RTRS-certified soy in animal feed; soy in feed for animals meant for non-domestic consumption should comply with the FEFAC Sourcing Guidelines.

\subsection{Measuring impact}

Measuring the contribution of the transition to certified soy use in Dutch animal feed covers both the 'supply' and the 'demand' side. The supply side concerns the extent to which the specific purchase of certified soy by Dutch stakeholders makes the cultivation of soy in the countries of origin more sustainable. The demand side concerns the extent to which Dutch companies contracts its suppliers to use certified soy and the extent to which certified soy replaces conventional (non-certified) soy. This project developed indicators and methods to measure the impact on the supply and demand side and identifies data sources for these indicators. These indicators, methods and data sources are being used subsequently in 2013, 2014 and 2015 to analyse the annual progress of the transition and its impact.

The project closely cooperated with the impact assessment projects in the soy supply chain of IDH and the involved NGOs such as WWF Netherlands and Solidaridad.

As a first step, a list of about 100 indicators were identified by joint discussions of the parties involved in the project, against which data could be collected. Parties had different background and ample experience in soy production related sustainability issues. Selection of the indicators was based on a theory of change for improving the sustainability of the soy value chain (Figure 2.1). A theory of change (ToC), also called a results chain, a causal chain or impact logic, is a visual tool designed to show not only what the activities of an intervention/project are but also how the different activities of an intervention/project are expected to lead to the long-term impact objectives of the 
intervention/project. A ToC also contains both Output and Outcome objectives, which illustrate the various steps from activity to impact. In general terms a ToC is designed to clarify the 'logic' behind an intervention/project. Given the way in which it is designed a ToC also forms the basis for assessing if and to what extent change is taking place and to what extent the intervention is contributing to this change. By visually illustrating how the links in an interventions ToC are believed to be related to each other, a ToC draws attention to the inherent assumptions that have been made in the design of the intervention and asks those responsible for the implementation of the intervention to consider the possible negative and/or unintended consequences of the interventions activities.

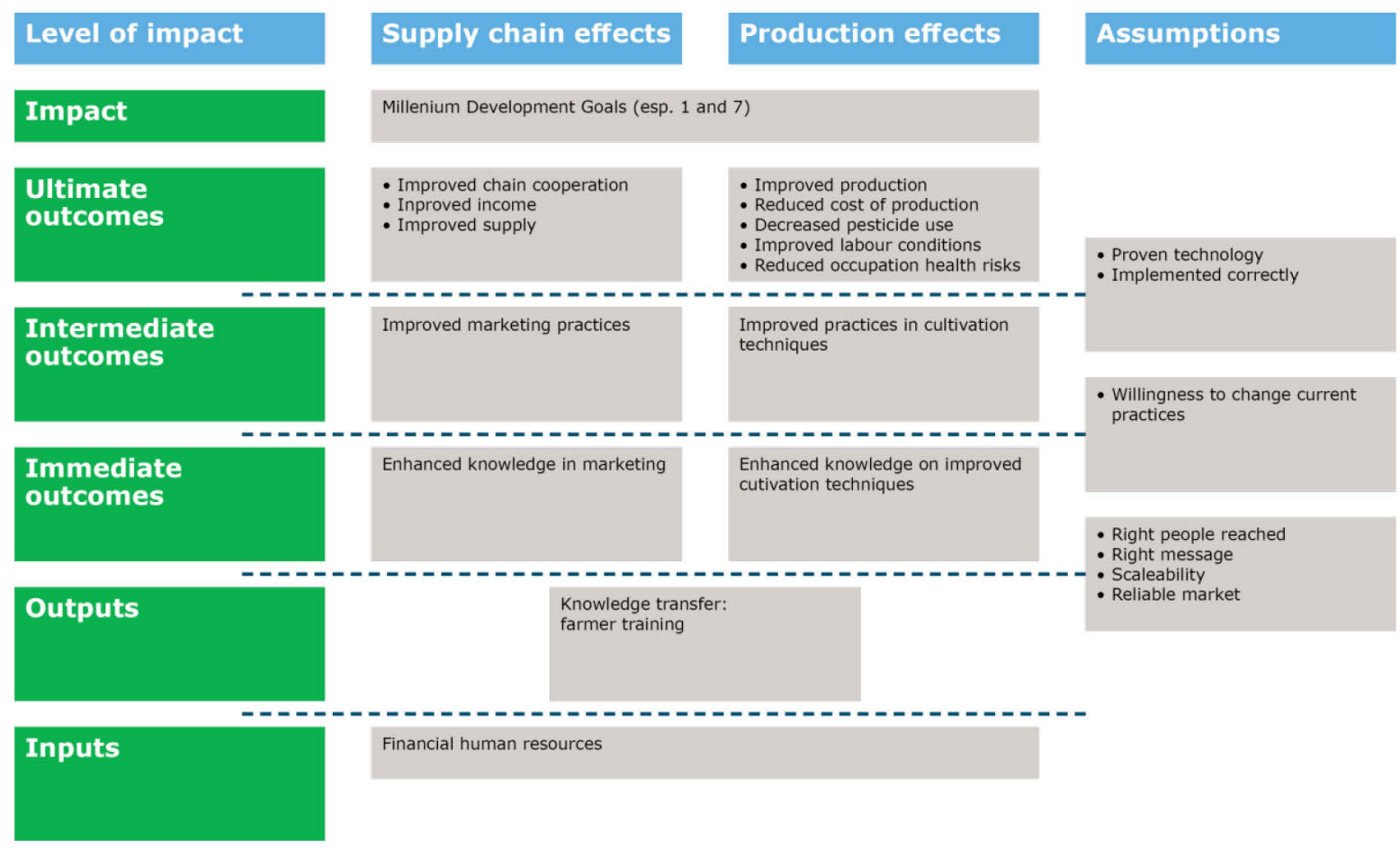

Figure 2.1 Theory of Change in the impact analysis

Note: From the Millennium Development Goals, especially Goal 1 (Eradicate extreme poverty and hunger) and Goal 7 (Ensure environmental sustainability) are focused at.

The selection of relevant and suitable indicators was also based on the following criteria:

- Limited number of meaningful indicators - to efficiently collect data

- In line with current challenges of data collection and areas of attention in RTRS

- Considering the availability of data (e.g.: audit reports)

- Data collection partly done by partners as they are close to soy producers

- Focus on RTRS only

The selected indicators were placed in 4 groups, namely Economic, Environment, Social and Purchase indicators. In this way the project has developed a systematic approach to assessing the transition towards certified production that is applicable to a wide range of agricultural products and commodities. After a process of reduction, which involved all related institutions in the project, a list of 45 parameters was sent to all 36 projects covering 138 certified and 530 RTRS certifiable South American soy farmers in the sample. Certifiable farms are compliant with RTRS criteria, but not yet certified for economic reasons. However, data collection was hampered, as feedback was limited in number of responses, as well as in data quality (completeness), even after repeated requests. This led to a limited number of parameters presented in the impact analysis. 


\subsection{Data collection for Impact analysis}

The data for the RTRS soy production impact analysis (Section 4) are collected within the projects. The creation of the Stichting Ketentransitie Verantwoorde Soja (SKT) in the Netherlands to collectively stimulate the demand for certified soy in the Netherlands and Europe, was accompanied by the creation of the Soy Fast Track Fund (SFTF) by IDH, to directly support traders and producers to produce the required certified soy and create impact. Through purchases of credits for certified soy the SKT members supported transition of farms to RTRS soy production. These investments in credits were also accounted as co-funding into the SFTF field projects, together with supplying traders (eg. Amaggi, Cefetra, Nidera). The projects of SFTF in general were chosen, as close as possible to the sourcing areas from the members of the Stichting Ketentransitie and other European buyers. Almost all projects were selected in so-called risk prone areas in terms of biodiversity, forest degradation and social issues. The IDH projects represent about half of the worldwide RTRS soy production during the project period.

The main challenge was to get information from soy producers. In our first report we concluded 'Willingness to cooperate increased over time and takes time as it is a multi-stage approach and requires trust' (Hoste and Judge, 2015). After a number of years the data collection has improved, but not all previously chosen indicators could be collected.

Over time the list of indicators had to be limited, as data was hardly or not available, and results for some indicators are not comparable, e.g. use of pesticides was insufficiently reported and given the nature of pesticides' use (related to diseases and weather circumstances), hardly comparable over time and between farmers.

The developed method is characterised by a collaborative search for a set of indicators, and bridges gaps in (partly) opposite interests. However, data availability has appeared to be limiting factor. In order to deal with the limited quantitative information we added some testimonials of producers and stakeholders. 


\section{Demand for animal products produced with certified soy}

\subsection{Introduction}

Section 3 gives the results of the impact assessment related to the demand for certified soy and animal products for which certified soy was used. Purchase indicators have been defined and measured in a) the support of the transition towards RTRS (Section 3.2), b) quantification of certified soy use (Section 3.3), c) sector ambitions, industry standards and retail and supply chain agreements (Section 3.4). Certified soy is defined as soy where the production is compliant with FEFAC Sourcing Guidelines, with special attention to RTRS-certified soy.

\subsection{Support to transition towards RTRS}

The commercial and institutional support to the transition towards certified soy is measured with two indicators. The first indicator is the number of companies and other entities being a member of RTRS, as far as they are based in the Netherlands, or supplying to Dutch companies (Table 3.1). Membership is assumed to show support to societal issues related to soy production and the market share of companies involved is assumed to indicate the interest to those issues per sector. Membership or application of other standards is not publicly known. Additional to the numbers in Table 3.1 are some internationally active companies and organisations with Dutch links, like Shell, WWF and Control Union.

Table 3.1 Dutch RTRS members and traders supplying the Dutch market, split into companies and other (NGOs and related), different years

\begin{tabular}{lccccc} 
Type & 2012 & 2013 & 2014 & 2015 & 2016 \\
Companies & 23 & 25 & 30 & 35 & 31 \\
\hline NGOs and related & 5 & 5 & 6 & 6 & 5 \\
\hline Total & 28 & 30 & 36 & 41 & 36 \\
\hline
\end{tabular}

Source: responsiblesoy.org and RTRS personal communication (2016, 2017).

Table 3.1 shows an increase in companies being member of RTRS until 2015 and a decrease in 2016. Figure 3.1 shows the market relevance of the Dutch company RTRS members per sector. E.g. Soy traders, being member of RTRS, represent an estimated 95\% (rounded number) of the soy supply to the Dutch market. The dairy industry and supermarket organisations in the Netherlands are also highly involved, whereas about half of the feed industry and pork industry is member and the broiler meat and egg processors are less represented in RTRS. Overall more than half of the market share of the sectors involved is represented. This, however, is limited to market shares per sector and not related to soy consumption per sector. Market shares are were estimated based on expert judgement. Retail, food, oil and feed industry sector organisations are not included in these market shares. Appendix 2 gives a complete overview of the Dutch RTRS members and RTRS suppliers to the Dutch market. 


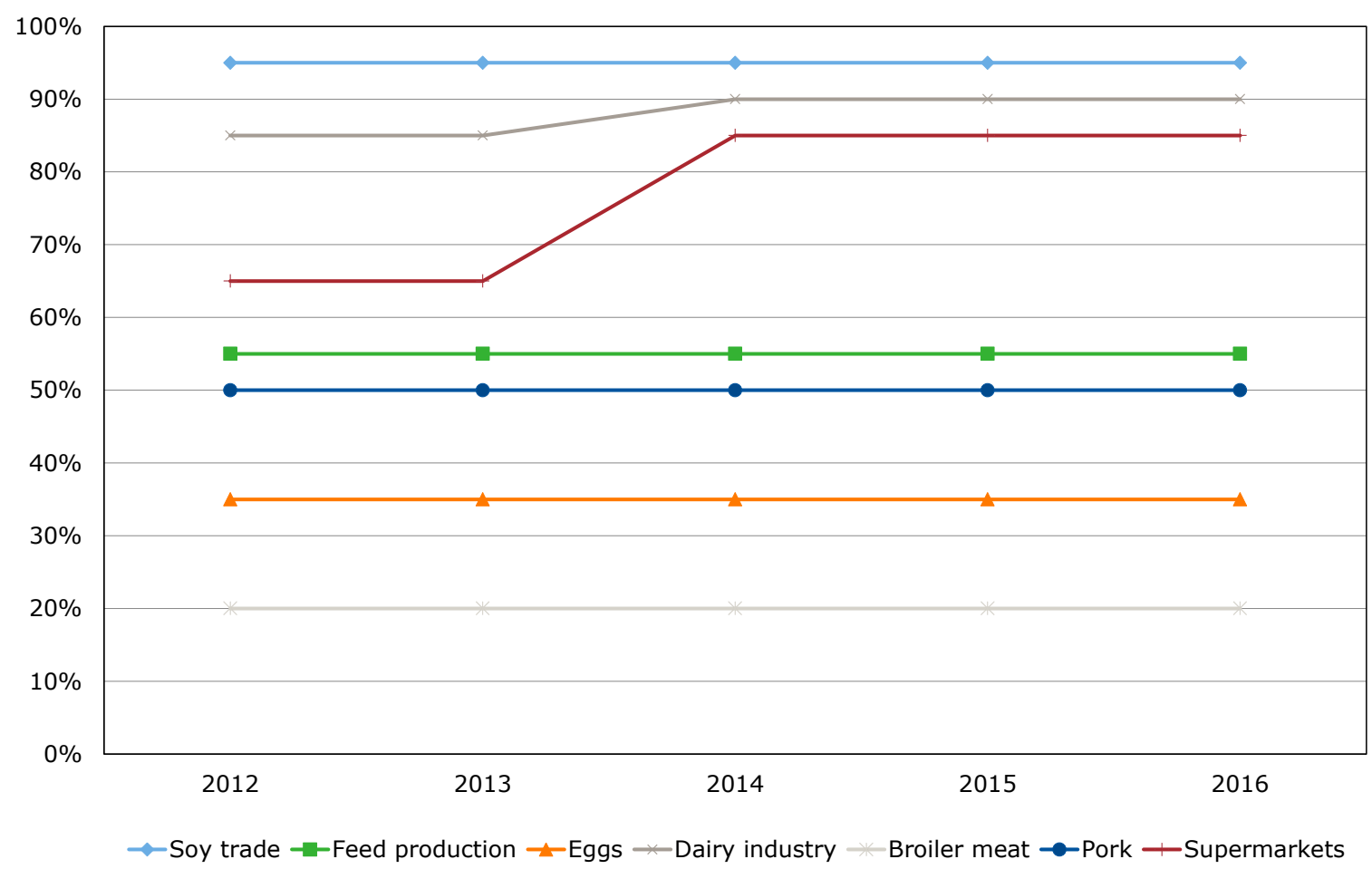

Figure 3.1 Indicative market share (volume) of Dutch companies who are members of RTRS in selected sectors (rounded numbers)

Source: Wageningen Economic Research estimates.

\subsection{Quantification of purchased soy}

This section gives an overview of certified soy use, with special attention to RTRS. Also the relevance of the Dutch RTRS soy demand in the total RTRS soy production is shown. Trade of certified soy is performed in different supply chain models (Box 1 ).

\section{Box 1 Supply chain models for certified soy trade}

Segregated - certified soy is kept separate from other product throughout the entire supply chain.

Mass Balance - soy of different production specifications (e.g. certified and non-certified RTRS soy) is being mixed. Certificates are being traded along with the physical flow, according to the actual volume of certified soy. Control on the mass balance is being performed on every stage of the supply chain.

Book \& claim - Certified soy and product certificates (credits) are being traded separately, meaning that certified soy is being mixed with other soy. Certificates prove that production has taken place according to the specific standard.

Area mass balance - a book and claim system where the physical product flow and the credits come from the same region.

Volumes of purchased RTRS soy are increasing over time from 315,000 tonnes in 2012 to over $1.2 \mathrm{~m}$ tonnes in 2017 (Table 3.2). The share of certified soy increased from $28 \%$ in 2012 to $100 \%$ as of 2015, of which 55\% RTRS soy in 2016 and $72 \%$ in 2017. 
Table 3.2 Certified soy purchase in the Netherlands: tonnes and shares (\%), split into supply chain models

\begin{tabular}{|c|c|c|c|c|c|c|}
\hline Indicator & 2012 & 2013 & 2014 & 2015 & 2016 & 2017 \\
\hline Total soy purchase & $1,800 \mathrm{a})$ & $1,800 \mathrm{a})$ & $1,800 \mathrm{a})$ & 1,690 & 1,740 & 1,720 \\
\hline Intended volume of certified soy & 500 & 1,000 & 1,500 & 1,800 & 1,800 & 1,800 \\
\hline Total RTRS-certified soy & 315 & 417 & 253 & 756 & 1,015 & 1,240 \\
\hline Share of RTRS (\%) in total soy purchase & $18 \%$ & $23 \%$ & $14 \%$ & $45 \%$ & $58 \%$ & $72 \%$ \\
\hline Guidelines excl. RTRS & b) & $128 \mathrm{c})$ & $250 \mathrm{c})$ & 746 & 835 & 809 \\
\hline
\end{tabular}

Notes: a) Estimates; b) not known; c) Volumes refer to soy according to the Certified Responsible Soy Standard of Cefetra.

Sources: Wageningen Economic Research estimates; Nevedi.

In the years 2012 to 2014, soy food oil was included in the ambition of Stichting Ketentransitie. Total soy food oil use was estimated at about 80,000 tonnes per year (Esselink, personal communication, 2016). In 2012, 20,000 tonnes credits were purchased by MVO, in 2013 this was 40,000 tonnes and in 2014, 17,500 tonnes credits for food oil. After 2014, Nevedi pursued the ambition of SKT, but this was restricted to soy for animal feed. According to Klap (personal communication, 2016) the main volumes of soy for animal feed in 2015 and 2016 were probably traded according to the Book \& Claim system.

According to responsiblesoy.org, the website of RTRS, Dutch companies and organisations purchased higher amounts of credits than the total amounts mentioned in Table 3.3. E.g. in 2016, the credits purchased by Dutch agro-related companies amounted to some $1.55 \mathrm{~m}$ tonnes of credits for RTRScertified soy. This is different from the $1.240 \mathrm{~m}$ tonnes of credits purchased according to Table 3.2 in 2016, which might relate to the fact that companies also buy credits for their business or customers abroad.

Hoste (2014) calculated a total use of $1.8 \mathrm{~m}$ tonnes of soy in the animal feed industry in the Netherlands (excluding hulls). This is divided into 439,000 tonnes for the dairy and beef production, 494,000 tonnes for the pig production, 795,000 for the poultry production and 32,000 tonnes for other kind of animals. However, volumes may differ between years.

The total volume of certified soy in 2017 amounts to $1.72 \mathrm{~m}$ tonnes. This amount is $96 \%$ of the estimated total demand of the feed industry in the Netherlands of $1.8 \mathrm{~m}$ tonnes (Hoste, 2014). Nevedi (Klap, personal communication) states that this $1.7 \mathrm{~m}$ tonnes fully covers the soy purchase of their members. Nevedi represents almost the entire feed industry in the Netherlands. Given the fluctuating soy contents of animal feed over time, it is reasonable to state that the feed industry in the Netherlands virtually fully used certified soy as of 2015. The increased soy demand in 2016 and 2017 is to be explained by increased feed demand of dairy cows.

Dutch purchase of RTRS soy represented 30\% of RTRS soy world production in 2017 (Table 3.3). This means a direct Dutch link to about 380,000 ha through purchase of soy and credits. The substantial demand from the Netherlands in terms of volumes is also reflected in the fact that about half of the buyers of RTRS credits is Dutch (own estimate of data on www.responsiblesoy.org).

Table 3.3 Dutch share in world RTRS soy uptake

\begin{tabular}{|c|c|c|c|c|c|c|}
\hline Indicator & 2012 & 2013 & 2014 & 2015 & 2016 & 2017 \\
\hline Total production RTRS soy (in thousands of tonnes) & 970 & 1,125 & 1,382 & 2,054 & 3,208 & 4,089 \\
\hline Total area RTRS soy (in thousands of hectares) & 331 & 431 & 452 & 644 & 1,012 & 1,249 \\
\hline Dutch share in world RTRS soy uptake & $32 \%$ & $37 \%$ & $18 \%$ & $37 \%$ & $32 \%$ & $30 \%$ \\
\hline
\end{tabular}

Source: responsiblesoy.org; elaboration Wageningen Economic Research. 


\subsection{Ambitions, standards and agreements}

\subsubsection{General programmes and schemes}

This Section starts with some general programmes and schemes, followed by an overview of schemes per animal category.

Several animal sectors have set up an Integrated Chain Control (IKB) system several years ago, including for pigs, broilers, eggs, veal and beef, dairy (Keten Kwaliteit Melk) and goat's milk (Kwaligeit). Typically these quality systems are widely implemented, but have no requirement regarding certified soy.

Milieukeur is a quality label, managed by Stichting SMK. Certification schemes of Milieukeur are available for both food and non-food. For animal products, schemes are available for beef, broilers, eggs, and pigs. Certified soy is required in the schemes for eggs and pigs as of July 2014, and from 2015 for broilers. To this end the GMP+ FRA module MI102 has been developed. For beef, certified soy is an option of choice.

The Beter Leven hallmark has been developed by the animal protection organisation Dierenbescherming since 2007. Sets of animal welfare requirements have been defined for several animal categories: laying hens, broilers, pigs, beef cattle, veal calves and rabbits. The system has three levels, reflected by up to three stars. With one star, the basic housing requirements are increased to some extent, whereas with three stars (especially organic) outdoor is obliged. In January 2018, the Beter Leven programme had no requirements regarding certified soy.

Organic animal production is governed by European legislation. At least $95 \%$ of feed ingredients should be organic. Due to limited availability however, especially of protein ingredients, there is no $100 \%$ guaranteed organic source.

\subsubsection{Sectoral ambitions related to certified soy}

The goal of Stichting Ketentransitie (SKT) was to come to $100 \%$ certified domestic soy use $(1.8 \mathrm{~m}$ tonnes/year) in 2015. Stichting Ketentransitie discontinued according to plan and the ambition was pursued by Nevedi.

Nevedi, the umbrella organisation of the feed industry in the Netherlands pursued SKT's sector ambition (Nevedi, 2017). However, the ambition was amended. For domestic consumption of animal products RTRS-certified soy was to be used (600,000 tonnes/year); for other animal production the necessary soy in animal feed should comply with a soy standard according to FEFAC Guidelines (1.2m tonnes/year). The implementation towards $100 \%$ certified soy increased over the year 2015 . The RTRS requirement for domestic consumption of animal products is a consequence of the retailers' agreement $(\mathrm{CBL})$ as well as effort by dairy supply chain organisation Duurzame Zuivelketen (DZK).

FEFAC issued Soy sourcing Guidelines as a reference to benchmark existing soy production schemes (Nevedi, 2016). The Guidelines are a professional recommendation for FEFAC member associations. The Guidelines comprise six groups of criteria: Legal compliance, Responsible working conditions, Environmental responsibility, Good agricultural practices, Respect for legal use of land/land rights, and Protection of community relations. The Guidelines include a number of verification requirements. Although the arrangements of supply chains are not a part of the Guidelines, FEFAC considers this an important aspect.

Existing production schemes can benchmark their requirements with the Guidelines and become recognized to be compliant. Up to June 201817 schemes have been recognised to be compliant with the Guidelines: AAPRESID-AC (Argentina), ADM Responsible Soybean Standard, Cargill Triple-S, Cefetra CRS 3.1, AIC FEMAS (Responsible Sourcing Module), BEMEFA, ISCC EU \& ISCC PLUS, RTRS, U.S. Soy Sustainability Assurance Protocol (USSEC), ProTerra, Bunge, AMaggi, DonauSoja, EuropeSoja, Sustainable Feed Standard, Coamo and Sustainable Farming Assurance Programme 
(Source: FEFAC). The compliant schemes cover soy production, as well as trade and processing. FEFAC aspires the Guidelines to be the minimum standard for the Western European animal production.

The retail sector in the Netherlands, represented by their umbrella organisation $\mathrm{CBL}$, and supported by all its members, agreed in 2011 to require certified soy (RTRS or equivalent) in their purchase specifications, growing to $100 \%$ as of 2015 . Sourcing should be based on RTRS Mass Balance or Area Mass Balance; in case this is not available, RTRS Book \& Claim is accepted.

Specific retailer programmes have been set up for fresh pig meat (Varkensvlees van morgen) and fresh broiler meat (Kip van morgen) in cooperation with supply chain representatives. These programmes cover more or less the requirements of Beter Leven (animal welfare), but include environmental and food safety requirements. Soy in animal feed in these programmes must be RTRS certified or equivalent. These programmes are GlobalGAP certified, referring to a GMP+ module for the feed requirements.

In terms of animal welfare requirements, the Beter Leven programme is more or less comparable to Varkensvlees van morgen and Kip van morgen. Retailers may or may not require certification, as the Beter Leven hallmark can be used for retail branding.

The dairy sector in the Netherlands issued its own supply chain wide sustainability standard, Duurzame Zuivelketen. Details are given in Section 3.4.7.

\subsubsection{Pig meat}

Varken van morgen, the CBL-borne programme requires RTRS or equivalent. As of 2015 for feed it is referred to the GMP+-module MI102, which means that RTRS-certified soy is used. According to CBL (2016) $94 \%$ of the sales of fresh pig meat in Dutch super markets is based on Varken van morgen (including Beter Leven), which means that almost all the fresh pig meat sold in super markets is produced from pigs being fed RTRS-certified soy. Although RTRS is not required for meat products, it is logical that most of the meat products will be produced according to the same standard, as ingredients for meat products are - at least partly - derived from the same pigs as for the fresh meat. However, this is not prescribed and so it is not guaranteed.

Milieukeur varkens is one of the Milieukeur programmes of SMK. As of July 2014, RTRS-certified soy is required in pig feed. In December 201393 farmers were producing under this scheme, supplying 210 supermarkets; in June 2014153 farmers were producing 430,000 fattening pig places, supplying 265 supermarkets of Jumbo and Dekamarkt (retailers). In 2015 some 500,000 pigs were produced with the Milieukeur hallmark, being sold for example at Jumbo and Deka. However, late 2015 the main Milieukeur users (Jumbo, Van Rooi Meat and Vion) left the programme (Source: SMK Jaarverslag 2015; 2016), resulting in no Milieukeur pig meat sales via supermarkets since 2016.

The Keten Duurzaam Varkensvlees, Milieukeur varkens and Beter Leven * programmes comply with the Varkensvlees van morgen requirements. As the Varkensvlees van morgen programme is not used as a brand or label, some retailers prefer to also carry the Beter Leven hallmark on their products.

According to Brummelaar (2017) almost 3m pigs with Beter Leven hallmark were being slaughtered in the Netherlands in 2016, produced by about 795 pig farmers. It is estimated that some $4 \mathrm{~m}$ pigs are needed to cover the sold volumes, which reflects about $40 \%$ of the pigs slaughtered in the Netherlands. The rest of the pigs and piglets produced in the Netherlands is being exported or sold via other domestic sales channels (like out-of-home).

\subsubsection{Broiler meat}

All the Dutch retailers agreed to adhere to the transition to the 'Kip van Morgen' standard. However, criticism of this by the Anti-Cartel Authority ACM (ACM, 2015) on the actual advantage for the consumer compared to the additional costs resulted in a standstill of the joint approach and a variety 
of retailer programmes initiated. These programmes typically at least comply with the Kip van morgen requirements. Main retailer Albert Heijn defined the so-called 'AH Kip' and Jumbo the 'Nieuwe Standaardkip', which was copied by smaller retailers like MCD and Boon ('Betere Kip'). Another retailer programme, reflecting at least the Kip van Morgen standard is Pluimgarantie (Coop, Spar). Retailer Dirk describes their programme with 'Van een langzamer groeiend ras' ('From a slower growing breed') and retailer Lidl describes their product as 'Kip met betere leefomstandigheden' ('A broiler with improved housing circumstances'). Pressure groups force retailers to change their 'plofkip' (standard fast-growing broiler) production requirements to a higher standard. As of 2015 for feed the GMP+module MI102 is referred to as the standard, which means that RTRS-certified soy is used.

As the Kip van morgen programme is not used as a brand or label, some retailers prefer to also carry the Beter Leven hallmark on their products. In 2015 about $17 \mathrm{~m}$ broilers with Beter Leven hallmark were being produced in the Netherlands (Dierenbescherming, 2015), in 2016 21.7m broilers were slaughtered (Brummelaar, 2017); this reflects about $10 \%$ of the domestic production.

The Milieukeur vleeskuikens programme for broilers included demands for certified soy as of 2015. However, the programme has an almost $0 \%$ market share in the production in the Netherlands. From December 2013 there was 1 farm with some 30,000 places, producing about 210,000 broilers per year (SMK Jaarverslag 2015; 2016). The product is not labelled as such in the retail.

According to CBL (2016) $94 \%$ of the fresh broiler meat sold in Dutch super markets was a more sustainable alternative, including Beter Leven, organic and other 'sustainable alternative' programmes, which means that almost all the fresh broiler meat sold in super markets is produced from broilers being fed RTRS-certified soy. This corresponds to about 30 to $35 \%$ of the broiler production in the Netherlands.

\subsubsection{Beef and veal}

Domestic consumption of beef in the Netherlands is largely based on old dairy cows. As certified soy use is required in the dairy supply chain, meat of old cows will be compliant with the certified soy requirement. Until 2014 the soy requirement in the dairy chain was limited to the value share of milk production, but since 2015 this is required for the entire soy consumption in dairy feed.

Other beef consumption comes from high quality domestic production and import (e.g. from Argentina, Ireland). The domestic production is very limited, and partly exported. For the imported product the soy source is not known. South American beef is typically pasture-based production, generally without using soy in feed; pasture-based production however is in some cases associated with deforestation.

Milieukeur Rundvlees for beef production exists as a producers' standard, but it is not implemented by producers. Certified soy is an option in this programme, not a demand.

According to CBL (2016) $26 \%$ of the fresh beef meat sold in Dutch super markets was produced according to the Beter Leven programmes; however, this does not imply soy requirements.

Veal for domestic consumption is produced entirely in the Netherlands. Producers must therefore comply with the Dutch feed industry standard of $100 \%$ certified soy as of 2015 . Veal calves for sales in the Dutch retail market must be fed RTRS-certified soy. However, soy consumption in veal production is very limited.

\subsubsection{Eggs}

As agreed in the retail umbrella organisation all eggs sold in Dutch supermarkets are produced with RTRS soy in the feed. According to CBL (2016) $43 \%$ of the eggs sold in Dutch super markets were produced according to the Beter Leven programmes, and $57 \%$ were so-called Scharrel eggs (barn eggs); however, this does not imply soy requirements. 
Milieukeur Eieren is the Milieukeur programme for eggs. The programme requires RTRS soy or equivalent as of July 2014 . The eggs produced under this programme have a turnover of $€ 2.8 \mathrm{~m}$ in 2013, which is some $1 \%$ of Dutch eggs. In 2015 there were some 125,000 laying hens on 4 farms, producing 29 million eggs with the Milieukeur hallmark (Source: SMK Jaarverslag 2015; 2016).

Rondeel eggs are produced according to the Milieukeur standard, with an additional requirement for ProTerra soy (non-GM segregated supply chain). As of December 2013, 3 layer farms follow the Rondeel programme, producing $27 \mathrm{~m}$ eggs/year. Eggs are mainly sold via 850 supermarkets of Albert Heijn. The market share of this programme amounts to $0.3 \%$ of Dutch egg production.

\subsubsection{Dairy}

Duurzame Zuivelketen (DZK) is the programme of the Dutch dairy supply chain, representing $98 \%$ of the production. DZK agreed to only use RTRS-certified soy for dairy production as of 2015. For 2014 DZK aimed to cover $83 \%$ of dairy soy use, based on an assumed volume of 200,000 tons. More recent calculations (Reijs et al., 2015) show higher soy use (544,000 tonnes per year including hulls). From 2015 , certified soy is guaranteed by a certification scheme. Dairy farmers are obliged to source from feed suppliers that certify (RTRS Book \& Claim) all soy needed in dairy concentrates. Originally it was the aim to incrementally evolve from credits (2015) to mass balance (2020). However, this requirement has changed, and DZK first wants to support sufficient 'critical mass' of certified book \& claim RTRS-certified, where after the transition will be made to $100 \%$ mass balance soy (GMP+, 2015; 2016). DZK includes the soy hulls in their programme.

According to CBL (2016) $11 \%$ of the turnover of dairy products sold in Dutch supermarkets were organic, and $71 \%$ were based on pasture grazing of the dairy cows.

\subsubsection{Animal feed}

The animal feed industry jointly agreed to only use certified soy for animal production aimed for domestic consumption, refering to the GMP+ Feed Responsibility Assurance Scheme to implement the soy requirements. The programme has modules for Dairy, as well as for Pig and Poultry feed. GMP+ issues the Scheme, but does not collect information on actual soy purchase per customer. For other animal production soy has to comply with the FEFAC Sourcing Guidelines.

For dairy feed, the GMP+ MI101 module is used, requiring 100\% RTRS soy for dairy production; hulls are included. Credits may be used, but DZK aims to change to Mass Balance as soon as sufficient 'critical mass' is available. June 2016, 178 feed and fourage companies were certified. (GMP+, 2016).

For pig and poultry feed the GMP+ MI102 module is to be followed by feed producers for the programmes Milieukeur Varkens, Milieukeur Vleeskuikens and Milieukeur Eieren. Hulls are not taken into account in this scheme. June 2016, 41 feed companies were certified (GMP+, 2016).

Nevedi collects information on actual soy purchase with their members, and the uptake of certified soy being RTRS or otherwise complying to FEFAC Sourcing Guidelines.

\subsubsection{Retailers}

Several Dutch retailers have been changing their assortment towards programmes with increased animal welfare requirements. To give an exhaustive overview over programmes is hardly possible, as programmes are changing over time, and a differentiation is made between fresh meat and meat products and even some products were exempted from the programme due to limited availability (as was the case with pig tenderloin with Albert Heijn). Some retailers prefer to carry the Beter Leven hallmark on their products, alongside the Varkensvlees van morgen and Kip van morgen programmes.

It can however be concluded that retailers are changing their assortment towards a higher level of animal welfare requirements. As far as soy is concerned, all supermarket organisations in the Netherlands have agreed to adhere to the goal of using $100 \%$ certified soy in the production of animal 
products by 2015. This holds for imported products as well. According to CBL (2016) all soy in sold products in Dutch super markets was RTRS soy and $99 \%$ of the palm oil in sold products was based on RSPO or equivalent programmes.

Retailers Albert Heijn, Jumbo, Ekoplaza, purchase organisation SuperUnie and some of its individual members (with a total market share of about $83 \%$ in 2015; source: Distrifood) refer to only using certified soy on their website. Aldi and Lidl do not refer to any soy agreement or strategy on certified soy, but are required to comply with it as CBL members. ${ }^{1}$

No retailer standard is known for certified soy for dairy products (milk, cheese), as the dairy industry jointly set up its own DZK standard (including soy demands).

1 Source: Based on rank-a-brand. 


\section{Impacts on soy production}

\subsection{Introduction}

In this chapter the results are presented for the supply side indicators. Section 4.2 quantifies the RTRS soy production in Brazil, Argentina and Paraguay. Section 4.3 describes projects on certified soy production, being the base for the data collection of the impact analysis. Sections 4.4 and 4.5 describe results of the Economic and Social responsibility analysis. Only the indicators where data was sufficiently available, are presented. A full list of the indicators, including those for which data resulted difficult to collect or was insufficiently available, is included in Appendix 1. Additional to quantitative results, some testimonials on the contribution of RTRS certification on soy producing farms are presented.

\subsection{RTRS soy production}

As a background to the project and in order to place Dutch efforts including those of IDH, in perspective, data are first provided on the total production of soy and RTRS soy worldwide (Table 4.1), and more specifically in South America (Table 4.2). The total number of RTRS-certified soy producers grew in 2016 to 34,549 , the increase is mainly due to large numbers of small holders in India (Source: RTRS).

Table 4.1 RTRS soy production worldwide, years 2012-2016

\begin{tabular}{|c|c|c|c|c|c|c|}
\hline Indicator & 2012 & 2013 & 2014 & 2015 & 2016 & 2017 \\
\hline \# of RTRS-certified hectares ('000) & 331 & 431 & 452 & 644 & 1,012 & 1,249 \\
\hline $\begin{array}{l}\text { \# of RTRS-certified hectares share of total soy } \\
\text { area worldwide }(\%)\end{array}$ & 0.31 & 0.39 & 0.38 & 0.54 & 0.84 & 1.04 \\
\hline $\begin{array}{l}\text { Total production RTRS-certified soy (tonnes * } \\
1,000)\end{array}$ & 970 & 1,125 & 1,382 & 2,054 & 3,208 & 4,089 \\
\hline RTRS Credits bought (tonnes) & 503 & 710 & 1,313 & 2,157 & 1,915 & 2,203 \\
\hline
\end{tabular}

Source: www.responsiblesoy.org; estimates based on Faostat.

South America is the main contributor to the global RTRS soy production, of which $82 \%$ is produced in Brazil, followed by $13 \%$ in Argentina and 2\% in Paraguay (2017) (Figure 4.1). 


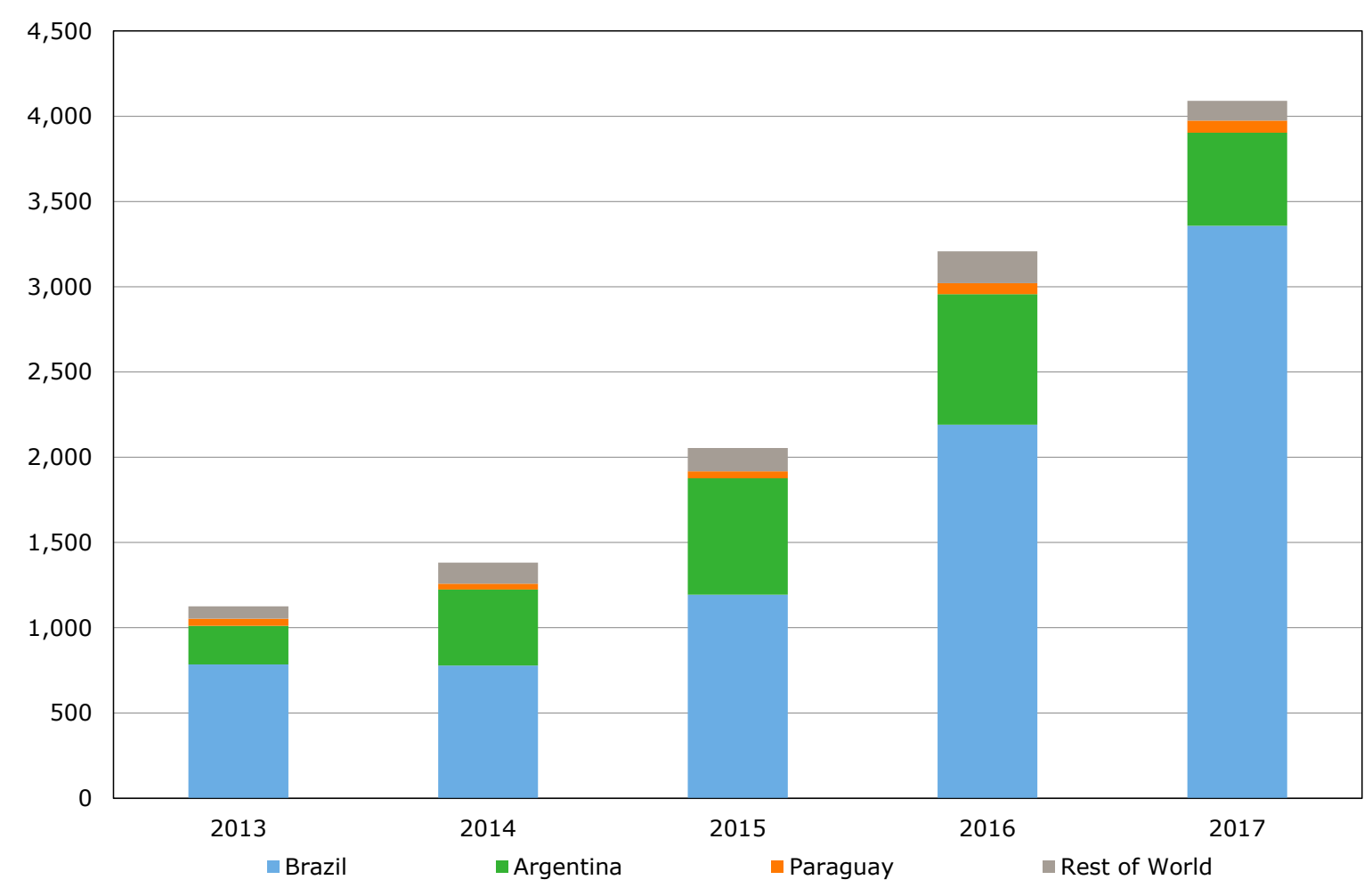

Figure 4.1 Increase of RTRS soy production in Brazil, Argentina, Paraguay and the rest of the world, 2013-2017

Source: www.responsiblesoy.org; Faostat; FAS-USDA; own calculations.

Still the RTRS production has a small share in the total production: $2.9 \%$ in Brazil, $0.9 \%$ in Argentina and $0.7 \%$ in Paraguay.

\subsection{Projects on certified soy production}

IDH contributed to the transition towards certified soy production through its Soy Fast Track Fund (SFTF). Many projects led by soy traders, producer organisations and NGOs, have been cofunded and implemented by IDH to help improve the production practices on participating farms. The SFTF and its partners supported 939 farmers owing 1,014 farms, through 27 projects: 22 in Brazil, 12 in Argentina and 3 in Paraguay. In total $€ 17.7 \mathrm{~m}$ was invested by the private partners, and co-funded with $€ 6.5 \mathrm{~m}$ by IDH. The SFTF was managed by Solidaridad Latin America on behalf of IDH. Projects were either linked to buyers in Europe and international traders, or were based on initiatives taken by local producer organisations, local traders or NGOs. Contribution in providing investments also came from the European side, especially the companies and associations participating in the Dutch Stichting Ketentransitie Verantwoorde Soja, in the Belgium Animal Feed Association Bemefa and the Swedish Lantmännen, who contributed through direct sourcing of certified soy from the countries and areas where certified soy was being produced.

Figure 4.2 gives a map with a sample of farms in IDH projects in Brazil and Argentina. Each dot (Brazil) and droplet (Argentina) represents a farm. Farms tend to be concentrated in clusters and show the main regions where the SFTF was active in Brazil and Argentina. No projects in Paraguay could be used for data collection as cooperation was limited. 


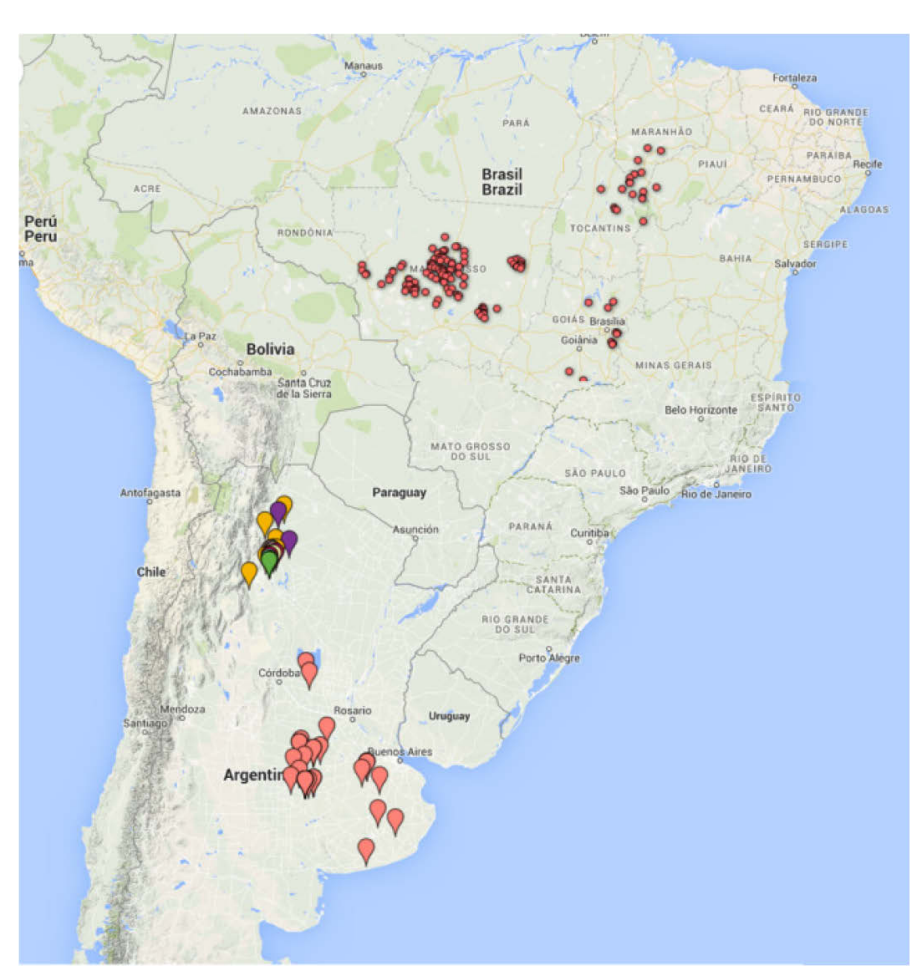

Figure 4.2 Map with farms in IDH projects in Brazil (dots) and Argentina (droplets)

Table 4.2 lists the total area under RTRS-certified land use by SFTF project partners in the period 2012-2016 along with the area on farms owned by project partners that are considered conserved high conservation value areas (in general tropical rainforest or high value tropical tree savannahcerrado or chaco).

IDH defined so-called priority areas; these are risk prone areas in terms of biodiversity, forest degradation and social issues. The SFTF focused on these areas as these imply serious sustainability improvement opportunities and functioned as an example for certified production practices (in some of these areas this was new).

The SFTF evolved its programme over the years to also support farmers that improved farm management, often preparing for certification, but not choosing yet for final certification, due to lack of buying interest in RTRS credits at that moment in time. Farmers do not want to pay for auditing and certification if they can't sell certificates. Therefore the SFTF also registered farms that reached the level of certification without having performed the certification itself, therefore 'deemed certifiable' farms. Table 4.2 gives the area of soy production in both categories. IDH and Solidaridad (2017) give more details on the outcomes and lessons learned in the SFTF programme between 2011 and 2016.

Table 4.2 Area of soy production across all IDH projects

\begin{tabular}{|c|c|c|c|c|c|}
\hline Indicator & 2012 & 2013 & 2014 & 2015 & 2016 \\
\hline $\begin{array}{l}\text { \# of certified RTRS hectares across all } \\
\text { IDH projects ( } x 1,000 \text { ha })^{2}\end{array}$ & 248 & 265 & 355 & 469 & 469 \\
\hline
\end{tabular}

Sources: IDH, IDH annual reports.

NB: NA = data not available/provided.

\footnotetext{
2 Results are cumulative.
} 


\subsection{Environmental sustainability within sample}

The contribution of production under RTRS requirements on environmental sustainability is measured with two kinds of indicators: protected area and pesticides' use.

Legislation in Brazil requires farms to have part of the farm area to be protected natural area. The share of the total area depends on the region and ecosystem/biome, from $20 \%$ to $80 \%$ (e.g. higher conservation requirement in the Amazon biome than elsewhere). The new Forest law requires producers to register the protected natural area. Table 4.3 shows that on average some $40-50 \%$ of the area is protected area (51\% in 2016). As RTRS requires beyond legal compliance, RTRS-certified producers are more in front in this development. It is not known whether this is a consequence of RTRS certification or if farms complied already before certification. A number of producers have a protected area beyond legal requirements, local Forest Code, or Legislation, in total of about 50,000 ha in 2014, 132,000 ha in 2015 and 101,000 in 2016. In 2015 some farmers could not comply with final requirements to keep RTRS certification. Therefore the total protected area apparently is lower in 2016, however it may be assumed that the protected status of the forest has not changed.

Table 4.3 Cultivated and protected areas (* 1,000 ha) on farms in IDH projects

\begin{tabular}{|c|c|c|c|}
\hline Indicator & 2014 & 2015 & 2016 \\
\hline Cultivated area & 580 & 1,893 & 1,714 \\
\hline Protected area on RTRS-certified farms & 66 & 336 & 328 \\
\hline Share of protected area in total cultivated area & $44 \%$ & $42 \%$ & $51 \%$ \\
\hline $\begin{array}{l}\text { Protected area above legal requirements and Forest code all } \\
\text { farms }\end{array}$ & 50 & 132 & 101 \\
\hline $\begin{array}{l}\text { Share of protected area above legal requirements and } \\
\text { Forest Code in total protected area }\end{array}$ & $19 \%$ & $17 \%$ & $11 \%$ \\
\hline
\end{tabular}

Source: IDH annual reports.

Data collected and provided for the Pesticides' use and pest management indicators was limited despite efforts throughout the project to improve the process of data collection. Still too many farms in the sample do not report on it. This might relate to the need of trust-building and of convincing the advantage of benchmarking. The same holds to the reporting on health and safety accidents related to agrochemical use on the farms. A number of farmers reported substantial improvements in agrochemical application and integrated pest management.

Farmers have been asked on their investments in agrochemical storage and disposal management in order to attain certification and legal compliance. The total investments amounted to USD0.48m in 2014, USD2.27m in 2015 and USD2.63m in 2016. A clear increase in total investment on the reporting farms is seen.

\subsection{Social sustainability}

Indicators on staff, relationship to the local community and compliance with law and standards were defined. Indicators include focus on Persons employed from the local community, Quality of dialogue \& communication (response to complaints between farms and local community organisations), Improvements made by farms to achieve compliance with legislation and standards, and Number of employees trained and educated professionally.

Regarding Dialogue and communication mechanisms, the Argentinian farms in the projects all stated to have such mechanisms in the years 2014 to 2016. Investments to achieve compliance with labour law and standards was reported by a limited number of farms; total reported investments amounted 
to USD3.5m in 2014, growing to USD4.1m in 2015 and USD6.0m in 2016. The total investment on the reporting farms is increasing.

\section{Box 2 Testimonials on positive effect of RTRS certification}

'The difference between a farm that has been part of our project and a traditional farm is clear. We notice the care with which pesticides, fertilizers and waste materials are handled and stored. We see the adjustments of the buildings to increase safety and health and we notice an awareness about nature preservation and sustainability.' Maurício Graziano, AGREX, Brazil.

'We started the project and could certify 9 properties. The farmers were very happy and proud. They started to tell people about the efforts they made to become certified and the importance of certification. They are now true advocates for RTRS. In the second stage of the project, we managed to add an additional 21 properties without much effort.' Cynthia Cominesi, CAT Sorriso, Brazil.

'The associated producers have the intention to complying with the law. They only need support and someone who shows them the way.' Gustavo Ruíz Díaz, Solidaridad Country Manager, Paraguay.

'Little by little we could convince the farmers that we were not there to inspect or fine them, but to assist them. We started by helping the farmers to comply to the legislation. Compliance to labour, safety and environmental legislation, decreases the risk of embargoes and fines.' Marizete Zuttion, Sindicato dos Produtores Rurais de Luis Eduardo Magalhães (SRLEM), Brazil.

'The program was implemented in Maranhão and Piauí, both states where poverty and misery are widely present. If we analyse the income per capita of Maranhão, for example, we will see that money circulates there where soy production is present. The economic base of soybean farms has improved, generating jobs and income. In addition to the implementation of sustainable soybean management, we have been able to explain internationally that soy has a social impact, which was very well accepted by credit buyers in Europe.' Gisela Introvini, FAPCEN, Brazil.

'I have adopted a technique taught in the Pest Management course to monitor caterpillars. By identifying caterpillars early, we can decrease the use of agrochemicals.' José Zuff, Cooperativa Raul Peña, Producer, Paraguay.

'In the heads of farmers, sustainability was some kind of mega project. We could show that also farmers with a small property can meet the criteria.' Janaína Monti Silveira, environmental analyst at AGREX.

Source: IDH and Solidaridad, 2017 (quoted with consent of IDH). 


\section{Discussion and conclusions}

Three topics are discussed here and conclusions are being drawn: on demand for certified soy, on measuring an impact in soy production an on outcomes of the analysis.

\section{Demand for certified soy}

The joint approach of the Dutch feed and animal production sectors and retail towards using certified soy in animal production has resulted into a transition to exclusively use certified soy. Certified soy is being defined as soy produced under specific production standards that comply with the FEFAC Sourcing Guidelines, like RTRS. In practice the feed industry prefers the term 'responsible' soy, a term which, however, is being opposed by NGOs.

The total volume of certified soy in 2017 used by the Dutch animal feed sector amounted to 1.72 million tons. The feed industry in the Netherlands fully used certified soy in as of 2015 . This is the result of retail agreements (for animal products meat, eggs and dairy, only RTRS or equivalent soy should be used in animal production), supply chain programmes (Varkensvlees van morgen, Kip van morgen, Duurzame Zuivelketen) and feed industry agreement.

The Dutch ambition to fully use RTRS-certified soy in 2014 has been amended into a two-track policy: for domestic consumption of animal products RTRS-certified soy was to be used; for other animal production the necessary soy in animal feed should comply with a soy standard according to the FEFAC Guidelines. In 2017, about $70 \%$ of the certified soy used by the Dutch feed industry $(1.240 \mathrm{~m}$ tonnes) is RTRS-certified soy. Herewith, the Netherlands is an important player in RTRS, using $30 \%$ of the worldwide RTRS soy uptake in 2017.

It can be concluded that the transition towards certified soy, by demanding sustainably produced soy, is being supported at the demand side of the supply chain, not only by word of mouth, but also by buying behaviour of the supply chain participants. The joint approach of all parts of the supply chain, as well as of all players in the retail part of the supply chain (competitors), driven by industry umbrella organisations and NGOs to perform this transition towards certified soy was successful.

The acceptation of certified soy on the Dutch market was measured by analysing the industry support, sector ambitions, industry standards and retail and supply chain agreements. This approach provides valuable insights into results of the transition to certified soy in consumer products.

\section{Measuring the impact in production}

Measuring the contribution of the transition towards certified soy on the sustainability of soy production has shown to be quite a challenge. Cooperation within the project group was positive and running well, in spite of (partly) opposite interests. Our approach is in line with Ingram et al. (2016), who recommended to work together with industry on efficient data collection, in order to build a robust monitoring and evaluation system.

The main challenge was to get information from soy producers. Setting up such an impact analysis needs time to build trust and to convince soy producers to cooperate. Consequently, it could make sense to repeat the impact analysis in the coming years and increase both the number of parameters and data quality.

It is concluded that the applied method gives insight into the contribution of the transition towards certified soy on the sustainability of soy production.

\section{Findings of the impact assessment}

A limited number of sustainability topics has been quantified. Regarding environmental sustainability, the protected area and pesticide use were measured. A total of 100,000 ha of land, of which $90 \%$ in 
Brazil, is protected area above legal requirements and Forest Code. This is no expansion of natural area, but merely a matter of registration of existing natural area, which makes nature conservation possible. As RTRS requires beyond legal compliance, RTRS-certified producers are more in front in this development, although it is unknown whether compliance was the starting position or a consequence of RTRS certification.

Farmers are also being asked on their investments in agrochemical storage and disposal management in order to attain certification and legal compliance. Although based on a limited number of farmers, total investments in agrochemical storage and disposal management in order to attain certification and legal compliance amounted to about USD2.6m.

All Argentinian farms in the sample stated to have installed Dialogue and communication mechanisms. Investments to achieve compliance with labour law and standards was reported by a limited number of farms; total reported investments amounted to USD3.5m in 2014, increasing to USD6.0m in 2016.

Based on these findings, it can be concluded that at least on some topics, an improvement has been achieved in the RTRS-certified soy producers. Also the testimonials tend to support that RTRS-certified soy production leads to less deforestation and less pesticides' use, as well as to improved management practices and societal awareness of producers. However, a comprehensive conclusion cannot be drawn, as the number of topics is very limited and the data to establish the causal effects of RTST were not available. 


\section{References and websites}

ACM (2015). Analyse ACM van duurzaamheidsafspraken 'De Kip van Morgen'.

https://www.acm.nl/sites/default/files/old_publication/publicaties/13758_analyse-acm-kip-vanduurzaamheidsafspraken-kip-van-morgen-2015-01-26.pdf

Brummelaar, T. (2017). Beter leven, geen beter rendement. 29 augustus 2017.

http://www.boerderij. nl/Home/Achtergrond/2017/8/Beter-leven-geen-beter-rendement-

176264E/; accessed 1 September 2017.

CBL (2016). Hoe duurzaam is de Nederlandse supermarkt?

Dierenbescherming (2015). Beter leven voor steeds meer dieren. 15 oktober 2015.

https://www. dierenbescherming. nl/wat-wij-doen/actueel/nieuws/nieuws-overzicht/beter-levenvoor-steeds-meer-dieren; accessed 24 August 2016

Distrifood. Marktaandelen 2007-2016 Nielsen. http://www. distrifood. nl/Service/Marktaandelen. Accessed 3 February 2017.

Fearnside, P.M. (2001). Soybean cultivation as a threat to the environment in Brazil. Environmental Conservation 28 (1): pp. 23-38.

FEFAC (2016). FEFAC Soy Sourcing Guidelines. http://www.fefac.eu/file.pdf?FileID=65744

GMP+ (2015). GMP+ Feed Certification scheme; Module: Feed Responsibility Assurance GMP+ MI102 Responsible pig \& poultry feed. Version: January 1st 2015.

https://www.gmpplus.org/bestand/22062/gmp-mi102---en-20150101.pdf.ashx

GMP+ (2016). GMP+ Feed Certification scheme; Module: Feed Responsibility Assurance GMP+ MI103 Responsible dairy feed. Version: 1 January 2016. https://www.gmpplus.org/bestand/32382/gmpmi103---en-20160101.pdf.ashx

Hoste, R. (2014). Sojaverbruik in de Nederlandse diervoederindustrie 2011-2013. Inventarisatie in opdracht van Stichting Ketentransitie verantwoorde soja. The Hague, LEI Wageningen UR, Nota 14-098.

Hoste, R. and L. Judge (2015). Impact evaluation of the Dutch transition to responsible soy - Progress 2014. The Hague, LEI Wageningen UR, Report 2015-040.

IDH Annual reports, several years.

IDH and Solidaridad (2017). Soy Fast Track Fund 2011-2016; Main results \& lessons learned. https://www.idhsustainabletrade.com/resource/soy-fast-track-fund-learning-report-eu-partners/

Ingram, V.J., L.O. Judge, M. Luskova, S. van Berkum and J. van den Berg (2016). Upscaling sustainability initiatives in international commodity chains; Examples from cocoa, coffee and soy value chains in the Netherlands. Statutory Research Tasks Unit for Nature \& the Environment (WOT Natuur \& Milieu). WOt technical report 67.

Kuit, M. and Y.R. Waarts (2014). Small-scale farmers, certification schemes and private standards: Is there a business case? Costs and benefits of certification and verification systems for small-scale producers in cocoa, coffee, cotton, fruit and vegetable sectors. The Technical Centre for Agricultural and Rural Cooperation (CTA), Wageningen, The Netherlands. 
Macedo, M.N., R.S. DeFries, D.C. Morton, C.M. Stickler, G.L. Galford and Y.E. Shimabukuro (2012). Decoupling of deforestation and soy production in the southern Amazon during the late 2000 s. PNAS 109(4): pp. 1341-1346, doi: 10.1073/pnas.1111374109

Nevedi, 2016. FEFAC Soy Sourcing Guidelines Factsheets. https://assets. nevedi.nl/p/229376/FEFACFactsheet_NL(1).pdf

Nevedi, 2017. Factsheet Verantwoorde soja. https://assets.nevedi.nl/p/229376/20170324\%20Factsheet\%20Nevedi\%20Verantwoorde\%20soja(3). pdf

Rank-a-brand. Sustainability: Supermarkets. http://rankabrand.org/supermarkets. Accessed 29 March 2016

Reijs, J.W., G.J. Doornewaard, J.H. Jager and A.C.G. Beldman (2015). Sectorrapportage Duurzame Zuivelketen; Prestaties 2014 in perspectief. The Hague, LEI Wageningen UR, LEI Report 2015-126.

SMK Jaarverslag 2015.

SMK Jaarverslag 2016.

Soy Coalition, 2015. Public NGO Statement on FEFAC Soy Sourcing Guidelines. September 10, 2015. http://soycoalition.org/?p=736

Waarts, Y., L. Judge, J. Brons (PBL) and M. de Ruyter de Wildt (2013). Upscaling the impact of sustainability certification initiatives; Enabling conditions and policy recommendations for regional development. The Hague, LEI Wageningen UR, Report 2013-046.

\section{Websites}

RTRS - www.responsiblesoy.org/

FAOStat - faostat.fao.org/

FAS-USDA - www.fas.usda.gov

Sites of various retailers and companies 


\section{Appendix 1 Original list of indicators}

\begin{tabular}{|c|c|}
\hline 1 & $\begin{array}{l}\text { Protected areas: obtain indication and evidence of positive effect of legal compliance and } \\
\text { certification on conservation and recovery of biodiversity }\end{array}$ \\
\hline 1,1 & of hectares of protected natural area/vegetation on certified farms in IDH projects \\
\hline 1,2 & $\begin{array}{l}\text { Total \# of hectares of protected natural area/vegetation on certified farms in IDH projects as a \% of total } \\
\text { hectares }\end{array}$ \\
\hline 1,3 & $\begin{array}{l}\text { Total \# of hectares of protected natural area/vegetation on farms in IDH projects that is above legal } \\
\text { requirements }\end{array}$ \\
\hline 1,4 & $\begin{array}{l}\text { Total \# of hectares of protected natural area/vegetation on farms in IDH projects that is above legal } \\
\text { requirements as a \% of total hectares }\end{array}$ \\
\hline 1,5 & $\begin{array}{l}\text { Total \# of hectares restored (riparian vegetation on farm, legal reserves on farm) elsewhere, including } \\
\text { above legal, since } 2009 \text {, as a result of activities on farm participation in IDH projects }\end{array}$ \\
\hline 1,6 & $\begin{array}{l}\text { Total \# of hectares restored (riparian vegetation on farm, legal reserves on farm) elsewhere, including } \\
\text { above legal, since } 2009 \text {, as a result of farm participation in IDH projects, as a } \% \text { of total hectares covered } \\
\text { by certified farms in IDH projects }\end{array}$ \\
\hline 1,7 & $\begin{array}{l}\text { Total \# of hectares compensated elsewhere, including above legal, since } 2009 \text {, as a result of farm } \\
\text { participation in IDH projects }\end{array}$ \\
\hline 1,8 & $\begin{array}{l}\text { Total \# of hectares compensated elsewhere, including above legal, since } 2009 \text {, as a result of farm } \\
\text { participation in IDH projects, as a \% of total hectares covered by certified farms }\end{array}$ \\
\hline 2 & $\begin{array}{l}\text { Management of native vegetation and riparian zone/wetlands on farm: obtain information on } \\
\text { implementation of RTRS biodiversity management tools }\end{array}$ \\
\hline 2,1 & $\begin{array}{l}\text { Total \# of farmers in IDH projects reporting plan as existing and (being) implemented (RTRS standard } \\
\text { principle 4.5.2) - HCV map existing if applicable }\end{array}$ \\
\hline 2,2 & $\begin{array}{l}\text { Total \# of hectares covered by farmers in IDH projects who report plan as existing and (being) } \\
\text { implemented (RTRS standard principle 4.5.2) - HCV map existing if applicable }\end{array}$ \\
\hline 3 & Conversion rate: for comparison reasons with indicator 1. \\
\hline 3,1 & Conversion rate (ha/year) of natural vegetation in regions where IDH projects are located \\
\hline 3,2 & $\begin{array}{l}\text { Total \# hectares of natural vegetation converted in regions where IDH projects are located, expressed as a } \\
\% \text { of total hectares }\end{array}$ \\
\hline 3,3 & Change in conversion rate (\% point) compared to previous year \\
\hline 4 & $\begin{array}{l}\text { Pest and Pesticide Management: to obtain evidence of smarter and diminished use of } \\
\text { agrochemicals }\end{array}$ \\
\hline 4,1 & $\begin{array}{l}\text { Quantity }(\mathrm{kg} / \mathrm{ha}) \text { of active ingredients of pesticide/herbicides used on farms in IDH projects in priority } \\
\text { areas, as defined above }\end{array}$ \\
\hline 4,2 & $\begin{array}{l}\% \text { difference between quantity }(\mathrm{kg} / \mathrm{ha}) \text { of active ingredients of pesticides/herbicides used on farms in IDH } \\
\text { projects in priority areas and local requirements }\end{array}$ \\
\hline 4,3 & $\begin{array}{l}\text { Quantity ( } \mathrm{kg} / \mathrm{national} \text { toxicity classification category) of pesticide/herbicides used on farms in IDH projects } \\
\text { in priority areas }\end{array}$ \\
\hline 4,4 & $\begin{array}{l}\% \text { difference between quantity ( } \mathrm{kg} / \text { national toxicity classification category) of pesticide/herbicides used on } \\
\text { farms in IDH projects in priority areas compared to previous year }\end{array}$ \\
\hline 4,5 & Quantity of Paraquat $(\mathrm{kg} / \mathrm{ha})$ used on farms in IDH projects in priority areas \\
\hline 4,6 & Quantity of Endosulfan $(\mathrm{kg} / \mathrm{ha})$ used on farms in IDH projects in priority areas \\
\hline 4,7 & \# farmers who report using Rotterdam/Stockholm pesticides on farms in IDH projects in priority areas \\
\hline 4,8 & $\begin{array}{l}\text { \# farmers who used Rotterdam/Stockholm pesticides on farms in IDH projects in priority areas in the year } \\
\text { before certification }\end{array}$ \\
\hline 4,9 & \# of registered Health and Safety accidents related to agrochemical use per year on farms in IDH projects \\
\hline 4,10 & $\begin{array}{l}\text { \# farmers in IDH projects reporting substantial improvement in appropriate agrochemical storage and/or } \\
\text { disposal management in order to attain certification and legal compliance (5.5) }\end{array}$ \\
\hline 4,11 & $\begin{array}{l}\text { \% area covered by farmers in IDH projects reporting substantial improvements in appropriate } \\
\text { agrochemical storage and/or disposal management in order to attain certification and legal compliance } \\
(5.5)\end{array}$ \\
\hline 4,12 & $\begin{array}{l}\text { \# farmers in IDH projects reporting substantial improvement in application of agrochemicals and use of } \\
\text { integrated pest management (IPM plan present at farm) in order to attain certification and legal } \\
\text { compliance }(5.4,5.7-5.9)\end{array}$ \\
\hline 4,13 & $\%$ area covered by farmers in IDH projects reporting substantial improvements in application of \\
\hline
\end{tabular}


agrochemicals and use of integrated pest management (IPM plan present at farm) in order to attain certification and legal compliance (5.4, 5.7-5.9)

4,14 \# of Farmers in IDH projects in priority areas trained in Biodiversity, Agrochemical use, waste disposal and other relevant practices (e.g. restoration with native trees, monitoring invasive species)

4,15 \# additional farmers in the region not directly involved in IDH projects who have adopted practices

4,16 Related positive policy changes in production areas where IDH projects are located, related to agrochemicals, adopted by producer organisations, chain partners, government, banks, retailers

4,17 \# of new farmers -outside IDH project areas- reached with implementation programmes, related to agrochemicals

5 General: to have indication of the scale and share of certified producers in area, volume and number of farmers, compared to regional and worldwide figures.

5,1 Description of all IDH projects (\#, size, location, business types)

5,2 \# of hectares of RTRS certification across all IDH projects

5,3 Total production (tonnes) of RTRS soy across all IDH projects

$5,4 \quad$ Average yield per farm ( $\mathrm{kg} / \mathrm{ha}$ ) across all IDH projects

$5,5 \quad$ \# of farmers participating in all IDH projects

5,6 \# of RTRS-certified hectares that these farmers represent

5,7 \# of hectares of RTRS certification directly included in IDH projects in priority areas

5,8 Total production (tonnes) of RTRS soy produced across IDH projects in priority areas

$5,9$ Average yield per farm ( $\mathrm{kg} / \mathrm{ha})$ across IDH projects in priority areas

$5,10 \quad$ \# of farmers participating in IDH projects in priority areas

5,11 \# of RTRS-certified hectares in priority areas that these farmers represent

5,12 \# of hectares of RTRS certification in the Stichting Ketentransitie sample

5,13 Total production (tonnes) of RTRS soy in the Stichting Ketentransitie sample

5,14 Average yield per farm $(\mathrm{kg} / \mathrm{ha})$ in the Stichting Ketentransitie sample

5,16 \# of farmers participating in IDH projects in the Stichting Ketentransitie sample

5,17 \# of RTRS-certified hectares in the Stichting Ketentransitie sample that these farmers represent

5,18 \# of farmers producing RTRS in priority areas

5,19 \# of farmers producing RTRS in priority areas as a \% of total \# of farmers

$5,20 \quad$ \# of hectares of RTRS production in priority areas

$5,21 \quad$ \# of hectares of RTRS production in priority areas as a \% of total soy area

5,22 Total RTRS production (tonnes) in priority areas

$5,23 \quad$ Average yield per farm ( $\mathrm{kg} / \mathrm{ha})$ in priority areas

5,24 \# of farmers producing RTRS in Brazil, Argentina, Paraguay

5,25 \# of farmers producing RTRS in Brazil, Argentina, Paraguay as a \% of total \# of farmers

$5,26 \quad$ \# hectares of production RTRS in Brazil, Argentina, Paraguay

5,27 \# hectares of production RTRS in Brazil, Argentina, Paraguay as a \% of total of soy area

5,28 Total production (tonnes) of RTRS in Brazil, Argentina, Paraguay

5,29 Total production (tonnes) of RTRS in Brazil, Argentina, Paraguay as a \% of total soy production

$5,30 \quad$ Average yield per farm ( $\mathrm{kg} / \mathrm{ha})$ in Brazil, Argentina, Paraguay

5,31 \# of farmers producing RTRS certification worldwide

5,32 \# of farmers producing RTRS certification worldwide as a \% of total farmers

5,33 \# of hectares of RTRS certification worldwide

5,34 \# of hectares of RTRS certification worldwide as a \% of total soy area

5,35 Total production (tonnes) of RTRS certification worldwide

5,36 Total production (tonnes) of RTRS certification worldwide as a \% of world soy production

5,37 Average yield per farm ( $\mathrm{kg} / \mathrm{ha}$ ) worldwide

5,38 Dutch Members of RTRS (policy on responsible soy) (from website RTRS)

$6 \quad$ Labour rights and standards: for an indication of the effects on workers, surrounding communities and impact on local development generally

6,1 \# of persons employed (year-round) on certified farms in IDH projects from local community IDH farms projects

6,2 \# of persons employed (year-round) on certified farms in IDH projects from local community, as a \% of total staff

6,3 Quality of dialogue \& communication, response on complaints, between farms in IDH project regions and local community organisations, e.g. Citizen organisation, farmer groups, associations, and local NGO's

(sample yearly)

6,4 Improvements made by farms in IDH projects to achieve compliance with law and standards, from 1 year before certification

6,5 Improvements made by farms in IDH projects to achieve compliance with law and standards, from 1 year 
before certification, in USD investments/year

6,6 \# of employees trained and educated professionally, made possible by IDH project

6,7 \# of employees trained and educated professionally, made possible by IDH project, in hrs training received

6,8 \# of employees trained and educated basic education, made possible by IDH project

6,9 \# of employees trained and educated basic education, made possible by IDH project, in hrs of training received

6,10 Local and regional social policies by sector organisations developed to improve community relations and social and economic development (\# of related new interventions, programmes, policy docs), in regions where IDH projects are located

6,11 Local and regional additional programmes and interventions to improve labour law compliance (\# of related new interventions, programmes regionally, \# policy docs), in regions where IDH projects are located

7 Purchase and market development: to have an indication on market uptake and sector embeddedness

$7,1 \quad$ Total purchase of responsible soy (RTRS \& equivalent) in tonnes SBEQ/year

$7,2 \quad$ Share (\%) of total soy purchase

7,3 Total responsible soy via Book \& Claim (credits) in tonnes SBEQ/year

7,4 Total responsible soy via Mass Balance in tonnes SBEQ/year

7,5 Total purchase of responsible soy oil in tonnes/year

$7,6 \quad$... Of which via Book \& Claim (credits)

7.7. $\ldots$ Of which via Mass Balance

7,8 Retailer standard on responsible soy in Pork (\%)

7,9 Retailer standard on responsible soy in Broiler meat (\%)

7,10 Retailer standard on responsible soy in Beef (\%)

7,11 Retailer standard on responsible soy in Eggs (\%)

7,12 Retailer standard on responsible soy in Milk (\%)

7,13 Retailer standard on responsible soy in Cheese (\%)

7,14 Retailer standard on responsible soy in Margarine (\%)

7,15 Overview of standards in Pork supply chain

7,16 Overview of standards in Broiler meat supply chain

7,17 Overview of standards in Beef supply chain

7,18 Overview of standards in Eggs supply chain

7,19 Overview of standards in Milk supply chain

7,20 Overview of standards in Cheese supply chain

7,21 Overview of standards in Margarine supply chain

7,22 Overview of standards in Animal feed

7,23 Overview of standards in A-brands (top \#)

7,24 Overview of standards of large processors 


\section{Appendix 2 Dutch RTRS members and RTRS suppliers to the Dutch market}

\begin{tabular}{|c|c|c|}
\hline Company & Type & First year of membership \\
\hline Agrifirm & Feed & 2008 \\
\hline AkzoNobel & Oil (industry) & 2009 \\
\hline Amsterdam Capital Trading BV & Finance & 2014 \\
\hline Archer Daniels Midland Company (Brazil) & Trade & 2007 \\
\hline Bunge Limited (US) & Trade & 2007 \\
\hline CARGILL Inc. (Brazil) & Trade & 2007 \\
\hline C.I.V. Superunie B.A. & Retail & 2012 \\
\hline CEFETRA GROUP & Trade & 2007 \\
\hline Danone & Dairy & 2016 \\
\hline De Heus Voeders B.V. & Feed & 2015 \\
\hline Dutch Protein \& Services BV & Meat & 2015 \\
\hline ForFarmers & Feed & 2010 \\
\hline FrieslandCampina & Dairy & 2007 \\
\hline Gebr Van Beek Group & Egg processing & 2009 \\
\hline GLENCORE GRAIN BV & Trade & 2007 \\
\hline GMP+ International & Certification & 2012 \\
\hline GROAN & Trade & 2014 \\
\hline Gruppo Andre Maggi (Brazil) & Trade & 2007 \\
\hline Hilton Meats Zaandam & Meat & 2015 \\
\hline IDH - Dutch Sustainable Trade Initiative & NGO & 2009 \\
\hline JUMBO Supermarkten B.V. & Retail & 2014 \\
\hline Kingdom of the Netherlands & Observer & 2014 \\
\hline KLM Royal Dutch Airlines & Catering & 2013 \\
\hline Louis Dreyfus Commodities & Trade & 2009 \\
\hline Marfo BV & Food products / catering & 2014 \\
\hline Meat Friends Roosendaal B.V & Meat & 2015 \\
\hline Menken Orlando & Food & 2016 \\
\hline MVO & Oil (industry) & 2007 \\
\hline NEVEDI & Feed & 2007 \\
\hline $\begin{array}{l}\text { Nidera Handelscompagnie BV (now: COFCO } \\
\text { International) }\end{array}$ & Trade & 2009 \\
\hline NUTRECO & Feed & 2007 \\
\hline Rabobank & Finance & 2007 \\
\hline Responsible Bizz & Consultancy & 2014 \\
\hline ROYAL AHOLD & Retail & 2007 \\
\hline Royal Zeelandia & Food Ingredients & 2016 \\
\hline Schouten Europe B.V. & Trade & 2013 \\
\hline Solidaridad & NGO & 2007 \\
\hline Storteboom Group B.V. & Meat industry & 2009 \\
\hline UNILEVER & Food products & 2007 \\
\hline VION NV & Meat industry & 2007 \\
\hline Vivera BV (former Enkco) & Meat substitutes & 2011 \\
\hline
\end{tabular}

Source: www.responsiblesoy.org and personal communication RTRS $(2016,2017)$.

Note: CBL - Dutch Food Retail Association (member since 2010), Natuur \& Millieu and CONO Cheesemakers (member since 2012), and Sligro

(member as of 2015) discontinued membership in 2016. 
Wageningen Economic Research P.O. Box 29703

2502 LS The Hague

The Netherlands

$\mathrm{T}+31(0) 703358330$

E communications.ssg@wur.nl

www.wur.eu/economic-research

Wageningen Economic Research REPORT

2018-003
The mission of Wageningen University \& Research is "To explore the potential of nature to improve the quality of life". Under the banner Wageningen University \& Research, Wageningen University and the specialised research institutes of the Wageningen Research Foundation have joined forces in contributing to finding solutions to important questions in the domain of healthy food and living environment. With its roughly 30 branches, 5,000 employees and 10,000 students, Wageningen University \& Research is one of the leading organisations in its domain. The unique Wageningen approach lies in its integrated approach to issues and the collaboration between different disciplines.

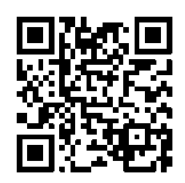





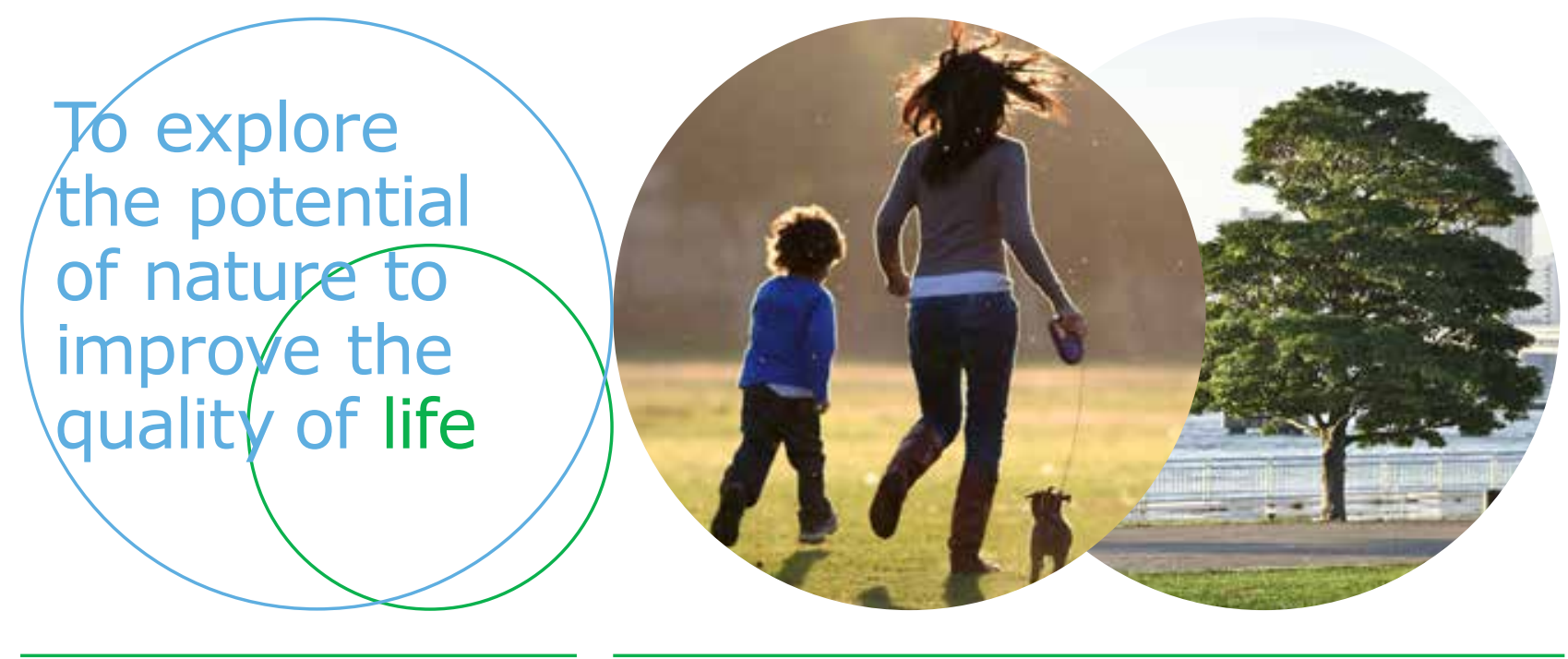

Wageningen Economic Research P.O. Box 29703

2502 LS Den Haag

The Netherlands

E communications.ssg@wur.nl

www.wur.eu/economic-research

Report 2018-003

ISBN 978-94-6343-780-6
The mission of Wageningen University \& Research is "To explore the potential of nature to improve the quality of life". Under the banner Wageningen University \& Research, Wageningen University and the specialised research institutes of the Wageningen Research Foundation have joined forces in contributing to finding solutions to important questions in the domain of healthy food and living environment. With its roughly 30 branches, 5,000 employees and 10,000 students, Wageningen University \& Research is one of the leading organisations in its domain. The unique Wageningen approach lies in its integrated approach to issues and the collaboration between different disciplines. 